Research note

\title{
Diaphanocephalus galeatus (Nematoda: Diaphanocephalidae), parasite of Salvator merianae (Squamata: Teiidae) in southern Brazil
}

Diaphanocephalus galeatus (Nematoda: Diaphanocephalidae), parásito de Salvator merianae (Squamata: Teiidae) en el sur del Brasil

\author{
Thainá Dutra Vieira*, Fabiana Fedatto-Bernardon, Gertrud Müller \\ Laboratório de Parasitologia de Animais Silvestres, Departamento de Microbiologia e Parasitologia, Instituto de Biologia, Universidade Federal de Pelotas, \\ Campus Universitário, caixa postal: 354, CEP 96010-900, Pelotas, Rio Grande do Sul, Brazil
}

Received 4 August 2015; accepted 22 January 2016

Available online 24 May 2016

\begin{abstract}
The gastrointestinal tract of 20 Argentine black and white tegu Salvator merianae, was examined in search of nematodes. The diaphanocephalid nematode Diaphanocephalus galeatus was identified with a prevalence of $80 \%$. This work contributes to the knowledge of the host's helminth diversity, being the first record in southern Brazil, and presents unpublished photographic records of the species.

All Rights Reserved (C) 2016 Universidad Nacional Autónoma de México, Instituto de Biología. This is an open access item distributed under the Creative Commons CC License BY-NC-ND 4.0.
\end{abstract}

Keywords: Argentine Black and White tegu; Reptiles; Nematodes; Parasitological indexes

\section{Resumen}

Se revisó el tubo gastrointestinal de 20 tegus argentinos Salvator merianae en busca de nematodos. Se encontró el diafanocefálido Diaphanocephalus galeatus con una prevalencia del $80 \%$. Este trabajo contribuye al conocimiento de la diversidad de helmintos del huésped, siendo el primer registro de la especie en el sur de Brasil y presenta registros fotográficos inéditos de la especie.

Derechos Reservados ( 2016 Universidad Nacional Autónoma de México, Instituto de Biología. Este es un artículo de acceso abierto distribuido bajo los términos de la Licencia Creative Commons CC BY-NC-ND 4.0.

Palabras clave: Tegu argentino; Reptiles; Nematodos; Índices parasitológicos

Parasites are among the most diverse and highly specialized organisms; they act as regulators of host populations, maintaining the integrity and stability of ecosystems (Brooks \& Hoberg, 2001; Windsor, 1995). Knowledge of endoparasites of wildlife is important for understanding the ecology, natural history, life cycle, and evolution of both parasite and host species (Silva et al., 2008). Studies on lizards in South America demonstrate

\footnotetext{
* Corresponding author.

E-mail address: thainadutravieira@hotmail.com (T.D. Vieira).

Peer Review under the responsibility of Universidad Nacional Autónoma de
} México. that these reptiles act as definitive hosts for several helminth species, mainly nematodes (Ávila \& Silva, 2010).

Salvator merianae (Duméril \& Bibron, 1839) (Squamata: Teiidae), known as the Argentine black and white tegu or teiú, is considered one of the largest South American lizards. It is found in eastern Bolivia, Argentina, Uruguay, and Brazil (Rio Grande do Sul, Mato Grosso do Sul, Goiás, Pará, Pernambuco, Amazonas, Maranhão, and introduced in the Fernando de Noronha archipelago) (Embert, Fitzgerald, \& Waldez, 2010; Loebmann \& Quintela, 2009).

This lizard species has a diurnal habit, living in fields, rocky areas, and forests near watercourses. It is omnivorous, with a 
varied diet consisting of fruits, insects, snails, fish, amphibians, reptiles, rodents, adult birds, nestlings, and eggs (Achaval \& Olmos, 2003).

Regarding the helminths parasites of $S$. merianae in South America, until now 6 nematodes species have been recorded: Cruzia travassosi Kalil \& Vogelsangi, 1932 (Kathlaniidae); Physaloptera retusa Rudolphi, 1819 (Physalopteridae); Diaphanocephalus galeatus (Rudolphi, 1819) (Diaphanocephalidae); Spinicauda spinicauda Olfers, 1819 (Heterakidae); Physaloptera tupinambae Pereira, Alves, Rocha, Lima, \& Luque, 2012 (Physalopteridae); Physaloptera bainae Pereira, Alves, Rocha, Lima, \& Luque, 2014 (Physalopteridae); and the cestode Oochoristica sp. (Cyclophyllidea) (Ávila \& Silva, 2010, 2011; Pereira, Alves, Rocha, Lima, \& Luque, 2012, 2014).

In southern Brazil there is no helminthological information related to $S$. merianae. Therefore, the aim of this study is to identify gastrointestinal nematodes inhabiting the intestinal tract of this lizard from municipalities of Rio Grande do Sul State, recording their parasitological indexes: prevalence, abundance and mean intensity of infection.

Twenty $S$. merianae were necropsied, 17 collected (already dead) on highways of southern Brazil from the municipalities of Pelotas $\left(31^{\circ} 46^{\prime} 19^{\prime \prime} \mathrm{S}, 52^{\circ} 20^{\prime} 33^{\prime \prime} \mathrm{W}\right)$, Capão do Leão $\left(31^{\circ} 46^{\prime} 3^{\prime \prime}\right.$ $\left.\mathrm{S} 52^{\circ} 26^{\prime} 55^{\prime \prime} \mathrm{W}\right)$, and Morro Redondo $\left(31^{\circ} 35^{\prime} 18^{\prime \prime} \mathrm{S}, 52^{\circ} 37^{\prime} 47^{\prime \prime}\right.$ W) under permission ICMBio $\mathrm{N}^{\circ} 38913-1$ issued to Instituto Chico Mendes de Conservação da Biodiversidade (ICMBio) $\left(\mathrm{N}^{\circ}\right.$ 38913-1); the remaining 3 animals were donated by Núcleo de Reabilitação da Fauna Silvestre and Centro de Triagem de Animais Silvestres of Universidade Federal de Pelotas (NURFSCETAS/UFPel).

The gastrointestinal tracts were sectioned into esophagus, stomach, and small and large intestines. These were opened and washed with a water jet through a $150 \mu \mathrm{m}$ sieve, and the resulting contents and mucous were examined under an Olympus SZ stereomicroscope. The nematodes were removed, quantified, fixed in AFA, and stored in alcohol $70^{\circ} \mathrm{GL}$. They were then mounted on semi-permanent slides with Aman's lactophenol, and viewed on an Olympus CX21 microscope for morphological and morphometric identification according to Freitas and Lent (1938) and Anderson, Chabaud, and Willmott (2009).

The measurements were expressed in millimeters (the mean and standard deviation shown in parentheses) and the photographs taken on an Olympus BX 41 microscope with attached camera system. The parameters calculated were prevalence, abundance, and mean intensity of infection according to Bush, Lafferty, Lotz, and Shostak (1997).

Voucher specimens were deposited in Coleção de Helmintos do Laboratório de Parasitologia de Animais Silvestres do Instituto de Biologia, Universidade Federal de Pelotas (CHLAPASIL/UFPel) $\left(\mathrm{N}^{\circ}\right.$ 605-611), Rio Grande do Sul, Brazil; Coleção Helmintológica do Instituto Oswaldo Cruz (CHIOC) ( $\mathrm{N}^{\circ}$ 6735-6737), Rio de Janeiro, Brazil; and Coleção de Invertebrados Museo de La Plata (MLP-He) ( ${ }^{\circ}$ 6843), La Plata, Argentina.

Diaphanocephalus galeatus (Rudolphi, 1819) Railliet \& Henry, 1909 (Fig. 1).
Characterization. Based on 96 specimens (10 males and 10 adult females were measured). Male: total body length $2.69-$ $4.5(3.48 \pm 0.58)$; width (in the half of body) $0.3-0.46(0.39 \pm$ $0.056)$; length of oral capsule $0.24-0.28(0.26 \pm 0.01)$; width of oral capsule $0.24-0.32(0.28 \pm 0.02)$; esophagus length 0.39 -0.48 (0.41 \pm 0.02$)$; esophagus width (maximum width) 0.17 $-0.27(0.21 \pm 0.02)$; nervous ring not visible; distance from the excretory pore to cephalic end $0.31-0.48(0.38 \pm 0.05)$; length of the largest spicule $0.58-0.84(0.68 \pm 0.08)$; length of the smaller spicule $0.4-0.49(0.44 \pm 0.03)$; length gubernaculum $0.18-0.51(0.28 \pm 0.12)$; length genital cone $0.29-0.3(0.29$ $\pm 0.007)$ (visualized in only 2 specimens). Female: total body length $2.19-5.62(4.28 \pm 1.01)$; width (in the half of body) $0.31-0.51(0.44 \pm 0.06)$; length of oral capsule $0.29-0.38$ $(0.32 \pm 0.03)$; width of oral capsule $0.3-0.39(0.34 \pm 0.03)$; esophagus length $0.42-0,57(0.49 \pm 0.04)$; esophagus width (maximum width) $0.19-0.30(0.23 \pm 0.03)$; nervous ring not visible; distance from the excretory pore to cephalic end $0.4-$ $0.62(0.5 \pm 0.09)$; distance from vulvar lip until the rear end $0.52-1.2(0.89 \pm 0.24)$; length of the vagina $0.37-1.1(0.70$ $\pm 0.28)$; length of ovejector $0.3-0.43(0.36 \pm 0.04)$; distance from the anus to end of tail $0.085-0.18(0.12 \pm 0.02)$; length of eggs $0.06-0.087$ ( $0.083 \pm 0.10)$; width of eggs $0.03-0.055$ $(0.041 \pm 0.005)$ (50 eggs were measured).

Diaphanocephalus galeatus was found parasitizing the stomach, small, and large intestine of $S$. merianae. Three hundred forty-six specimens were collected (195 females and 151 males) with a prevalence of $80 \%$, mean abundance 17.3 , and mean intensity of infection 21.6 per host. The presented photographic records are unpublished, so they are of important scientific value, considering that Freitas and Lent (1938) presented only illustrations in the description of the parasite.

In Brazil, the nematode was registered previously parasitizing S. merianae and Tupinambis teguixin (Linnaeus, 1758). In $S$. merianae this nematode species was reported in the states of Mato Grosso (Cuiabá, Chapada dos Guimarães, Poconé), Mato Grosso do Sul (Aquidauana, Serra da Bodoquena, Corumbá and its Nhecolândia district), and Pernambuco (specifically, Fernando de Noronha archipelago where the species was introduced) (Ávila \& Silva, 2011). In T. teguixin, D. galeatus have been collected in the states of Rio de Janeiro, São Paulo, Mato Grosso do Sul, and Rio Grande do Sul, as well as in Argentina and Bolivia (Freitas \& Lent, 1938; Vicente, Rodrigues, Gomes, \& Pinto, 1993). An additional host species Tupinambis rufescens (Günther, 1871) was recorded in Argentina (Spinelli, Fiorito, \& Stiebel, 1992).

The morphology and morphometry of males of D. galeatus found in this study agree with those described by Freitas and Lent (1938) in T. teguixin; however, females studied herein had slightly larger measurements (length and width of the esophagus, distance from the excretory pore to cephalic end, distance from vulvar lip until the rear end, and vaginal length) compared to those presented by the authors (length and width of the esophagus[0.368-0.400 and 0.216-0.240], distance from the excretory pore to cephalic end [0.368-0.416], distance from vulvar lip until the rear end and [0.520-0.872] and vaginal length [0.192-0.304]). 

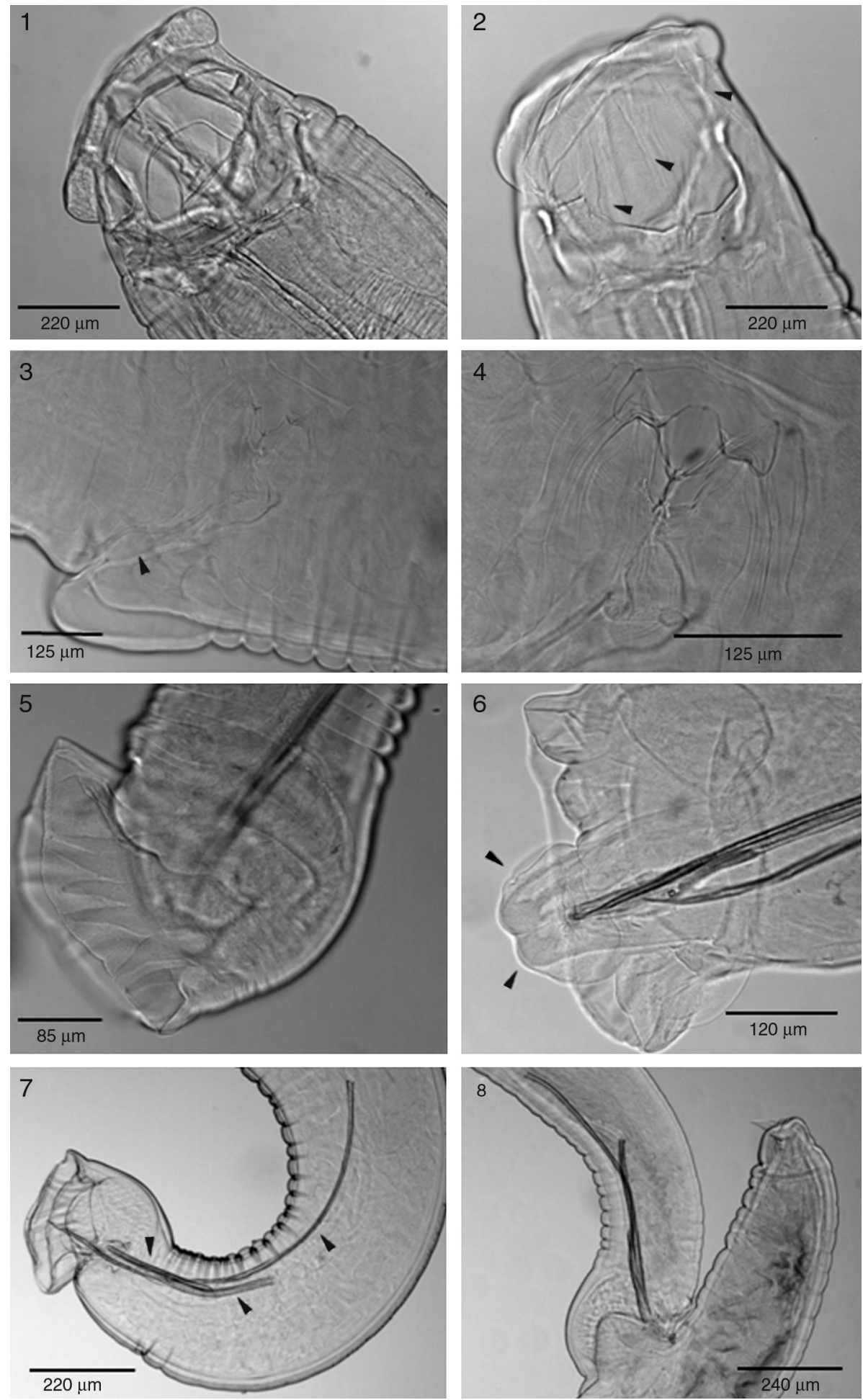

Figures 1-8. Diaphanocephalus galeatus (Rudolphi, 1819) parasite of Salvator merianae (Duméril and Bibron, 1839) of Southern Brazil. 1, Oral capsule; 2, arrows point the 3 pillars supporting both oral valves; 3 , arrow indicates the egg, vulvar lip of the female; 4 , ovejector of the female; 5 , male with closed copulatory bursa and apparent lateral rays; 6 , arrow indicates the genital cone of the male; 7 , arrows point gubernaculum, larger and smaller male spicules; 8 , posterior region of male and female copulating.

Previous records of $D$. galeatus in Brazil were made by Ávila (2009), who analyzed 18 specimens of $S$. merianae in several locations belonging to the Cerrado biomes and Pantanal: Cuiabá, MT $[P=100 \%$ and $I=20(n=2)]$; Poconé, MT $[P=100 \%$ and $I=2(n=1)]$; Chapada dos Guimarães, MT $[P=50 \%$ and $I=8$ $(n=2)]$; Serra da Bodoquena, MS $[P=50 \%$ and $I=18(n=2)]$; Corumbá, MS $[P=83.3 \%$ and $I=20.8(n=6)]$; Nhecolândia, MS $[P=100 \%$ and $I=13.7(n=3)]$; and Aquidauana, MS $[P=100 \%$ and $I=13(n=2)]$. On the other hand, Ramalho, Silva, Schwartz, and Péres (2009) analyzed 25 S. merianae lizards from the 
Fernando de Noronha archipelago, PE, finding D. galeatus with a prevalence of $96 \%$ and mean intensity of 20.5 , similar to those obtained in this work.

According to Spinelli et al. (1992), who studied D. galeatus from Tupinambis teguixin, this nematode parasite feeds on host tissue, resulting in lesions caused by the destruction of the intestinal mucosa through the mechanical action of their oral capsule, without causing ulcers in the affected area, only loss of tissue (i.e., an entry route for infection).

Studies on helminths associated with wild animals are important because they generate relevant information on the diversity of parasites, aiming to help understand the biology and ecology of their hosts. In this sense, the present study contributes to the knowledge of gastrointestinal nematodes of Salvator merianae and their parasitological indexes. This finding represents the first record of Diaphanocephalus galeatus in the Pampa biome, extending their geographic distribution to southern Brazil.

We thank the ICMBio for authorization, the NURFSCETAS/UFPel for donating dead lizards, and Coordenação de Aperfeiçoamento do Pessoal de Nível Superior for scholarships and financial support through edict 2010/032.

\section{References}

Achaval, F., \& Olmos, A. (2003). Anfíbios y reptiles del Uruguay ( $2^{a}$ ed.) Montevideo: Montevideo, Graphis.

Anderson, R. C., Chabaud, A. G., \& Willmott, S. (2009). Keys to the nematode parasites of vertebrates. London: UK: Ed. CABI.

Ávila, W. R. (2009). Padrões de infecção por helmintos em comunidades de lagartos do Brasil central. Thesis. Instituto de Biociências, Campus de Botucatu, Universidade Estadual Paulista, São Paulo.

Ávila, W. R., \& Silva, J. R. (2010). Checklist of helminths from lizards and amphisbaenians (Reptilia: Squamata) of South America. The Journal of Venomous Animals and Toxins including Tropical Diseases, 16, 543-572.

Ávila, W. R., \& Silva, J. R. (2011). Helminths of lizards (Reptilia: Squamata) from Mato Grosso State, Brazil. Comparative Parasitology, 78, 129-139.
Brooks, R. D., \& Hoberg, E. P. (2001). Parasites systematics in the 21st century: opportunities and obstacles. Trends in Parasitology, 17, 273-275.

Bush, A. O., Lafferty, K. D., Lotz, J. M., \& Shostak, A. W. (1997). Parasitology meets ecology on its own terms: Margolis et al. revisited. Journal of Parasitology, 83, 575-583.

Embert, D., Fitzgerald, L., \& Waldez, F. (2010). Salvator merianae. The IUCN Red List of Threatened Species. Version 2014.3. Retrieved on April 1, 2015 from: www.iucnredlist.org.

Freitas, J. F. T., \& Lent, H. (1938). Pesquisas helmintológicas realizadas no Estado do Pará, V. gênero Diaphanocephalus Diesing, 1851 (Nematoda: Strongyloidea). Memórias do Instituto Oswaldo Cruz, 33, 423-432.

Loebmann, D., \& Quintela, F. M. (2009). Guia ilustrado-os répteis da região costeira do extremo sul do Brasil. Rio Grande do Sul: USEB: Pelotas.

Pereira, F. B., Alves, V. P., Rocha, B. M., Lima, S. S., \& Luque, J. L. (2012). A new Physaloptera (Nematoda: Physalopteridae) parasite of Tupinambis merianae (Squamata: Teiidae) from southeastern Brazil. Journal of Parasitology, 98, 1227-1235.

Pereira, F. B., Alves, V. P., Rocha, B. M., Lima, S. S., \& Luque, J. L. (2014). Physaloptera bainae n. sp. (Nematoda: Physalopteridae) parasitic in Salvator merianae (Squamata: Teiidae), with a key to Physaloptera species parasitizing reptiles from Brazil. Journal of Parasitology, 100, 221-227.

Ramalho, A. C. O., Silva, R. J., Schwartz, H. O., \& Péres, A. K. (2009). Helminths from an introduced species (Tupinambis merianae), and two endemic species (Trachylepis atlantica and Amphisbaena ridleyi) from Fernando de Noronha Archipelago, Brazil. Journal of Parasitology, 95, 1026-1028.

Silva, A. S., Zanette, R. A., Tochetto, C., Oliveira, C. B., Soares, J. F., Otto, M. A., et al. (2008). Parasitismo por Physaloptera sp., Kalicephalus sp. e Cryptosporidium sp. em lagarto (Tupinambis teguixin) no Rio Grande do Sul, Brasil. Revista Brasileira de Zoociências, 10, 269-272.

Spinelli, C. M., Fiorito, L. E., \& Stiebel, C. (1992). Alteraciones histológicas em el intestino delgado em Tupinambis rufescens (Sauria, Teiidae) causadas por Diaphanocephalus galeatus (Nematoda, Diaphanocephalidae). Cuaderno de Herpetología, 7, 38-40.

Vicente, J. J., Rodrigues, H. O., Gomes, D. C., \& Pinto, R. M. (1993). Nematóides do Brasil, Parte III: Nematóides de répteis. Revista Brasileira de Zoologia, 10, 19-168.

Windsor, D. A. (1995). Editorial: Equal rights for parasites. Conservation Biology, 9, 1-2. 